\section{Einfache organische Verbindungen in homogenen und heterogenen Systemen als offene oder latente Peroxidasemodelle von außerordentlicher Wirksamkeit}

\section{Alfons Krause}

Institut für anorganische Chemie der Universität Poznań (Polen)

(Z. Naturforschg. 21 b, 189-190 [1966] ; eingeg. am 18. Oktober 1965)

Auf der Suche nach neuen Peroxidasemodellen stießen wir in letzter Zeit auf verschiedene unkomplizierte organische Verbindungen, die sich als ausgezeichnete Redox-Katalysatoren erwiesen ${ }^{1}$. Als Substrat diente eine $\mathrm{H}_{2} \mathrm{O}_{2}$-haltige Indigocarminlösung, deren Entfärbungsgeschwindigkeit jeweils bestimmt wurde, wobei es sich teils um homogenkatalytische, teils um heterogenkatalytische Systeme handelte. So gehören beispielsweise die einfachen Alkohole als Peroxidasemodelle in die homogene Lösungskatalyse, während z. B. Anthrachinon eher im heterogenen System als wirksam zu betrachten ist. Obschon die homogenen Modelle zahlreicher vertreten sind, sind sie nicht immer die aktiveren, wie dies erst kürzlich am heterogenen Benzophenon beobachtet wurde, das der bei weitem bessere peroxidatische Katalysator ist als eine homogene wäßrige Lösung von Aceton ${ }^{2}$. Daneben besteht aber noch ein weiterer wichtiger Unterschied, demzufolge derartige organische Verbindungen entweder in offene oder latente Peroxidasemodelle einzuteilen sind. Da, um ein Beispiel zu nennen, die einfachen Zucker und Alkohole schon von sich aus über $\mathrm{OH}$-Gruppen verfügen, die die Funktion von Wirkgruppen übernehmen können, so sind diese Verbindungen von vornherein mit den gewünschten strukturellen Akzessorien ausgestattet, die von einem Peroxidasemodell zu erwarten sind, so daß ein solches als offene Peroxidase zu bezeichnen ist. An den OH-Wirkgruppen kann nämlich nach Deformierung der $\mathrm{H}_{2} \mathrm{O}_{2}$-Molekel, evtl. unter Zwischenbildung von $\mathrm{HO}$ und $\mathrm{HO}_{2}$-Radikalen, die Indigocarmin-Oxydation ausgelöst werden, deren Mechanismus bereits bekannt ist ${ }^{3}$. Wenn man dagegen feststellt, daß auch verschiedene Ketone stark peroxidatisch wirken ${ }^{2}$, so ist man zunächst überrascht, da hier die strukturellen Voraussetzungen fehlen, welche die redox-katalytischen Eigenschaften dieser Stoffklasse rechtfertigen würden. Nun darf man allerdings nicht übersehen, daß in dem $\mathrm{H}_{2} \mathrm{O}_{2}$-haltigen
Medium der peroxidatischen Indigocarmin-Entfärbung der bewußte Katalysator oxydativen Veränderungen ausgesetzt ist, in deren Verlauf $\mathrm{OH}-$ Wirkgruppen als neue Struktureinheiten entstehen können, die daraufhin das katalytische Geschehen beeinflussen. Solche Verbindungen, wie die erwähnten Ketone, die also erst nachträglich unter dem Einfluß von $\mathrm{H}_{2} \mathrm{O}_{2}$ ihre katalytischen Eigenschaften erwerben, sind daher als latente resp. potentielle Peroxidasemodelle zu betrachten, die übrigens in ihrer Wirkung den offenen Peroxidasen keineswegs nachzustehen brauchen. Als gute Beispiele dieser Art sind Fumar- und Maleinsäure zu nennen ${ }^{4}$, wobei noch eine weitere Möglichkeit ins Auge zu fassen wäre, nämlich eine mögliche Dehydrierung der zukünftigen (im Moment latenten) Peroxidase. Vielleicht würden dabei, bevor weitere, evtl. schon inaktive Oxydations-Produkte aufkommen, vorübergehende Radikale auftreten, die die katalytische Reaktion in Gang bringen:

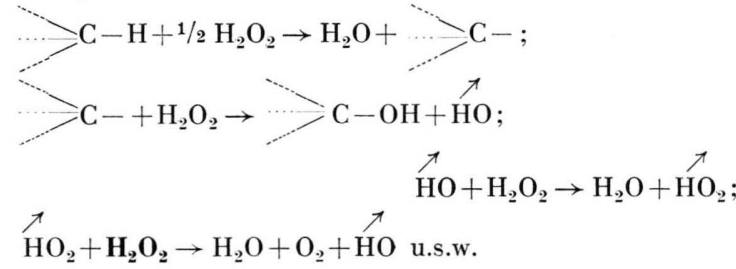

Wenn statt $\mathbf{H}_{\mathbf{2}} \mathbf{O}_{\mathbf{2}}$ sich Indigocarmin in das System einschaltet, so wird es durch das $\mathrm{HO}_{2}$-Radikal oxydiert, wonach das $\mathrm{O}$-ärmere HO-Radikal zurückbleibt, das nach weiterem Umsatz mit $\mathrm{H}_{2} \mathrm{O}_{2}$ die notwendigen $\mathrm{HO}_{2}$ Radikale wieder aufkommen läßt, womit die Reaktionskette sich zugleich schließt ${ }^{3}$. Bisher wurden unter den einfachen organischen Verbindungen zahlreiche Peroxidasemodelle beider Typen angetroffen ${ }^{1,3}$, die in Tab. 1 auszugsweise zusammengestellt sind.

In diesem Zusammenhang sei noch über ein neues Beispiel von latenten Peroxidasemodellen kurz berichtet, die wir soeben unter den Cl-Abkömmlingen des Methans gefunden haben ${ }^{5}$. Die Prüfung erstreckte sich auf $\mathrm{CH}_{2} \mathrm{Cl}_{2}, \mathrm{CHCl}_{3}$ und $\mathrm{CCl}_{4}$, deren peroxidatische Wirkung im Vergleich mit den in Tab. 1 genannten Verbindungen zwar schwach, aber dennoch in der gewünschten Stufung derart zu Tage trat, daß $\mathrm{CCl}_{4}$ als $\mathrm{H}$-freie Verbindung keine Merkmale einer potentiellen Peroxidase hat und daher praktisch wirkungslos ist. $\mathrm{Fe}^{3 \oplus}$-Ionen $\left(10^{-5} \mathrm{~g}\right.$, in einer Verdünnung von

\begin{tabular}{|c|c|c|c|c|c|}
\hline $\begin{array}{c}\text { Einfache } \\
\text { Alkohole } \\
\text { of./ho. }\end{array}$ & $\begin{array}{c}\text { Mono- und } \\
\text { Disaccharide } \\
\text { of./ho. }\end{array}$ & $\begin{array}{c}\text { Salicyl- } \\
\text { säuren } \\
\text { of./ho. }\end{array}$ & $\begin{array}{c}\text { Fumar- und } \\
\text { Maleinsäure } \\
\text { lt./ho. }\end{array}$ & $\begin{array}{c}\text { Aceton } \\
\text { und Campher } \\
\text { lt./ho. }\end{array}$ & $\begin{array}{c}\text { Benzophenon und } \\
\text { Anthrachinon } \\
\text { lt./ht. }\end{array}$ \\
\hline
\end{tabular}

Tab. l. Offene (of.) und latente (lt.) Peroxidasemodelle im homogenen (ho.) und heterogenen (ht.) System.

1 A. Krause u. Mitarb., Experientia [Basel] 20, 426 [1964]; Naturwissenschaften 52, 158, 641 [1965]; Mh. Chem. 96, 1479 [1965] u. im Druck; Z. Naturforschg. 20 b, 627 [1965], und im Druck.

2 A. Krause u. E. Nowakowski, Z. Naturforschg. 20 b, 922 [1965].
3 Vgl. A. Krause, Z. Naturforschg. 20 b, 627 [1965].

4 A. Krause u. L. Wachowski, Experientia [Basel] 21, 618 [1965].

5 A. Krause u. E. Nowakowski, unveröffentlicht. 


\begin{tabular}{|c|c|c|c|c|c|c|c|}
\hline $\mathrm{CH}_{2} \mathrm{Cl}_{2}$ & $\mathrm{CH}_{2} \mathrm{Cl}_{2}+\mathrm{Fe}^{3 \oplus}$ & $\mathrm{CHCl}_{3}$ & $\mathrm{CHCl}_{3}+\mathrm{Fe}^{3 \oplus}$ & $\mathrm{CCl}_{4}$ & $\mathrm{CCl}_{4}+\mathrm{Fe}^{3 \oplus}$ & $\mathrm{Fe}^{3 \oplus}$ allein & $\mathrm{Blindprobe}$ \\
1080 & 410 & 1150 & 380 & 1210 & 460 & 580 & 1300 \\
\hline
\end{tabular}

Tab. 2. Peroxidatische Indigocarmin-Entfärbung bei $37^{\circ}$ an $\mathrm{CH}_{2} \mathrm{Cl}_{2}, \mathrm{CHCl}_{3}$ und $\mathrm{CCl}_{4}$ (je $12,5 \mathrm{mg}$ ) bei $\mathrm{Zusatz}$ von $0,01 \mathrm{mg}$ $\mathrm{Fe}^{3 \oplus}$. Angegeben ist die Entfärbungszeit in Minuten.

$1: 6$ Millionen) beschleunigen die katalytische Umsetzung, wobei $\mathrm{CHCl}_{3}$ etwas ergiebiger von dieser $\mathrm{Ak}$ tivierung Gebrauch macht (Tab. 2).

Zur Ausführung der Versuche löst man 12,5 mg der betreffenden Cl-Verbindung in $25 \mathrm{~cm}^{3}$ dest. Wasser (*) und versetzt diese Lösung nach Ablauf von 10 Min. mit $25 \mathrm{~cm}^{3} \mathrm{H}_{2} \mathrm{O}_{2}$ (1,2-proz.) sowie anschließend mit $10 \mathrm{~cm}^{3}$
Indigocarminlösung (=3,3 mg Farbstoff) bei $37^{\circ}$. Das einmal gründlich umgeschwenkte Reaktionsgemisch verbleibt zwecks Ermittlung der Entfärbungszeit ohne weitere Konvektion im Wasserthermostaten bei $37^{\circ}$. Bei Verwendung von $\mathrm{Fe}^{3 \oplus}$-Promotorionen $\left(1 \mathrm{~cm}^{3}\right.$ $\mathrm{Fe}\left(\mathrm{NO}_{3}\right)_{3}$-Lösung) erfolgt ihr Zusatz an der mit (*) bezeichneten Stelle.

\section{Electrometric studies on the formation of alkali arsenites}

\section{S. Bhatnagar and K. Govind}

Chemical Laboratories, Govt. College, Kota (Raj.) India

(Z. Naturforschg. 21 b, 190-191 [1966]; eingeg. am 22. Oktober 1965)

The formation and composition of different alkali arsenites, obtained by the interaction of $\mathrm{As}_{2} \mathrm{O}_{3}$ and $\mathrm{NaOH}$ in the ratios $1: 2,1: 4$ and $1: 6$, have been studied from $p_{\mathrm{H}}$ and Conductivity measurements. The titrations were carried out between the alkali arsenites so formed and hydrochloric acid. The $p_{\mathrm{H}}$ titrations were carried out by using glass electrode in conjunction with a saturated calomel electrode. Conductivity was measured by a conductivity meter with magic eye as visual indicator. The formation of $\operatorname{meta}\left(\mathrm{NaAsO}_{2}\right)$, pyro $\left(\mathrm{Na}_{4} \mathrm{As}_{2} \mathrm{O}_{5}\right)$ and ortho $\left(\mathrm{Na}_{3} \mathrm{AsO}_{3}\right)$ alkali arsenites were established at different $p_{\mathrm{H}}$ levels.

Meagre amount of literature is available on the electrometric studies of alkali arsenites at different $p_{\mathrm{H}}$ values. Venzetri ${ }^{1}$ obtained alkali-ortho-arsenites by treating $\mathrm{As}_{2} \mathrm{O}_{3}$ with $\mathrm{NaOH}$ in the ratio $1: 6$. LE. Duc ${ }^{2}$ prepared alkali-meta-arsenite by treating $\mathrm{As}_{2} \mathrm{O}$ and $\mathrm{NaOH}$ in the desired ratio. Cernnatesco and Meyer ${ }^{3}$ observed the formation of $\mathrm{NaAsO}_{2}$ when $\mathrm{As}_{2} \mathrm{O}_{3}$ and $\mathrm{NaOH}$ reacted in the ratio $1: 2$. They concluded their inferences by the freezing point depression measurements. Except for the above investigations, no systematic electrometric study appears to have been carried out on the formation and composition of alkali arsenites, particularly taking $p_{\mathrm{H}}$ into consideration. The present investigation is carried out by the coordination of $p_{\mathrm{H}}$ and conductometric titration between different alkali arsenites and hydrochloric acid.

\section{Experimental}

E. Merck's guaranted extra pure reagents $\mathrm{Al}_{2} \mathrm{O}_{3}$, $\mathrm{NaOH}$ and $\mathrm{HCl}$ were used. $\mathrm{As}_{2} \mathrm{O}_{3}$ was standardised by titrating against iodine solution and $\mathrm{NaOH}$ was mixed in the molar ratios of $1: 2,1: 4$ and $1: 6$ to get sodium meta, pyro, and ortho arsenites respectively. These

1 B. L. Venzethi, Gazz. Chem. Ital. 55, 106 [1925].

2 Marc. Le. Duc, V. S. 2, 319, 777, May 25. were then titrated with standard hydrochloric acid. The conductometric and $p_{\mathrm{H}}$ titrations were performed by taking $\mathrm{HCl}$ solution in the micro-burette and arsenites solution in the conductivity and electrode cells respectively. Titration cells in both the cases were kept in an electrically maintained thermostat. Conductance was measured on a conductivity meter with magic eye as visual indicator.

$p_{\mathrm{H}}$ measurements were carried out with a cambridge $p_{\mathrm{H}}$ meter (null diflection type), standardised against standard buffer solution. Curves were plotted between the $p_{\mathrm{H}}$ (observed) and the volume of the titrant added in ml. In case of Conductometric titrations, observed conductance was corrected for the dilution effect and the curves were plotted between corrected conductance and the volume of titrant added in ml. For the sake of brevity, only one indicative diagram has been given.

\section{Discussion}

Different arsenite solutions were prepared by treating $\mathrm{As}_{2} \mathrm{O}_{3}$ and $\mathrm{NaOH}$ in the ratios $1: 2,1: 4$ and $1: 6$. When $\mathrm{As}_{2} \mathrm{O}_{3}$ and $\mathrm{NaOH}$ are mixed in the ratio $1: 2$, sodium meta-arsenite is formed. On mixing $\mathrm{As}_{2} \mathrm{O}_{3}$ to $\mathrm{NaOH}$ in the ratio $1: 4$, pyro-arsenite is formed and on mixing $\mathrm{As}_{2} \mathrm{O}_{3}$ and $\mathrm{NaOH}$ in the ratio $1: 6$, orthoarsenite is formed according to the following reactions:

$$
\begin{aligned}
& \mathrm{As}_{2} \mathrm{O}_{3}+2 \mathrm{NaOH} \rightarrow 2 \mathrm{NaAsO}_{2}+\mathrm{H}_{2} \mathrm{O}, \\
& \mathrm{As}_{2} \mathrm{O}_{3}+4 \mathrm{NaOH} \rightarrow \mathrm{Na}_{4} \mathrm{As}_{2} \mathrm{O}_{5}+2 \mathrm{H}_{2} \mathrm{O}, \\
& \mathrm{As}_{2} \mathrm{O}_{3}+6 \mathrm{NaOH} \rightarrow 2 \mathrm{Na}_{3} \mathrm{AsO}_{3}+3 \mathrm{H}_{2} \mathrm{O} .
\end{aligned}
$$

It is clear from figure (1) Curve $\mathrm{A}$ that when $\mathrm{HCl}$ is added to $\mathrm{NaAsO}_{2}$ solution [equation (i)] a sharp deflection occurs at a point when the ratio of $\mathrm{NaAsO}_{2}+$ $\mathrm{HCl}$ is $1: 1$ showing the formation of sodium metaarsenite. The initial $p_{\mathrm{H}}$ of meta-arsenite solution is of the order of ten. On addition of $\mathrm{HCl}$, it gradually falls and when it attains the value of eight, an abrupt fall in $p_{\mathrm{H}}$ is observed. Thus the formation of sodium metaarsenite is indicated. Its formation is further confirmed from conductivity measurements (Curve A'). Conductivity first gradually rises and when the molar ratio of $\mathrm{NaAsO}_{2}$ and $\mathrm{HCl}$ reaches $1: 1$, an abrupt rise

3 I. R. Cernatesco and A. Meyer, Z. physik. Chem., Abt. A. 160, 305 [1932]. 